\title{
Anti-Proliferative and Apoptotic Effects of Polygonum Cuspidatum and its Bioactive Compound, Emodin, in Colorectal Carcinoma HT-29 cells
}

\author{
Pin Der Duh", Tsuey Pin Lin'², Shu Ching Huang'², Shih Ying Chen ${ }^{2 *}$, Chin Chen $\mathrm{Chu}^{3,4}$, \\ Jen Yin Chen ${ }^{3,5}$, Chin Hui Chen ${ }^{6}$
}

\footnotetext{
${ }^{1}$ Department of Food Science and Technology, Chia Nan University of Pharmacy and Science, Tainan, Taiwan, ROC

${ }^{2}$ Department of Health and Nutrition, Chia Nan University of Pharmacy and Science, Tainan, Taiwan, ROC

${ }^{3}$ Department of Anesthesiology, Chi-Mei Medical Center, Tainan, Taiwan, ROC

${ }^{4}$ Department of Recreation and Healthcare Management, Chia Nan University of Pharmacy and Science, Tainan, Taiwan, ROC

${ }^{5}$ Department of Senior Citizen Service Management, Chia Nan University of Pharmacy and Science Tainan, Taiwan, R.O.C

${ }^{6}$ Department of Health Leisure and Management, Yuanpei University of Science and Technology, HsinChu, Taiwan, ROC
}

\begin{abstract}
Antiproliferative and apoptotic effects of ethyl acetate from the root of Polygonum cuspidatum (EAPC) and its bioactive compound, emodin, in colorectal adenocarcinoma HT-29 cells were investigated. HPLC analysis of major compounds, cell viability by MTT assay, the Comet assay, determination of reactive oxygen species (ROS) levels, apoptosis assay by flow cytometry and Western blot analysis were conducted. The results show significant antiproliferative effects of EAPC, $\mathrm{IC}_{50}=141.4 \mu \mathrm{g} / \mathrm{mL}$, and emodin isolated from EAPC, $\mathrm{IC}_{50}=73.0 \mu \mathrm{g} / \mathrm{mL}$, on HT-29 cells. HT-29 cells which were exposed to EAPC and emodin exerted apoptosis, after annexin V FITC/PI staining. EAPC (at $200 \mu \mathrm{g} / \mathrm{mL}$ ) and emodin (at $100 \mu \mathrm{g} / \mathrm{mL}$ ) increase DNA damage in HT-29 cells by $75.6 \%$ and $67.8 \%$, respectively, supporting that apoptosis occurred when the cells were treated with EAPC and emodin. Cells treated with EAPC and emodin generated intracellular ROS. In addition, emodin at tested doses of $25-100 \mu \mathrm{g} / \mathrm{mL}$ suppressed nuclear factor $\kappa \mathrm{B}(\mathrm{NF} \kappa \mathrm{B})$ and enhanced activator protein 1 (AP-1), which are involved in both proliferation and apoptosis events. EAPC and emodin demonstrated significant anti-proliferation of HT-29 cells through their pro-oxidant activity and contribution to oxidative stress, which in turn leads to cell death. EPAC and emodin inhibited HT-29 cell growth via apoptosis and could be considered as potential candidates for anti-colorectal cancer treatment.
\end{abstract}

Keywords: Antiproliferation; Apoptosis; Polygonum cuspidatum; Emodin; HT-29 cell

\section{Introduction}

Several epidemiological studies have provided convincing evidence that a large body of cancer-related deaths is closely linked to unhealthy diet and lifestyle. Nowadays cancer is a major public health issue throughout the world ${ }^{[1]}$. Cancer treatment depends on the type and stage of cancer, including surgery, radiotherapy, chemotherapy, hormone therapy, biological therapies, bisphosphonates, bone marrow, stem cell transplants, complementary and alternative therapies. However, different cancer treatments have produced different side effects, including nausea, pain and fatigue, which can make patients uncomfortable and affect their ability to stick to their treatments ${ }^{[2]}$. Among different types of cancer, colorectal cancer was the third leading cause of cancer-related cases in Taiwan and the second leading cause in the United States in $2014^{[1]}$. So far current treatment of colorectal cancer generally employs surgical resection combined with chemotherapy and radiation therapy ${ }^{[3]}$. However, this treatment is not fully successful for late stage colorectal cancer patients $^{[3]}$. Consequently, search for novel and effective approaches to the treatment of this cancer is required. In addition, a number of studies have shown that high consumption of vegetables, fruits, photochemical and chemo preventive agents from natural products decreases the risk of colorectal cancer. Therefore, development of novel agents from plant-derived natural products can potentially provide a beneficial and valuable source for anti-colorectal cancer treatment.
Received date: November 19, 2017 Accepted Date: February 09, 2018 Published Date: February 12, 2018

*Corresponding author: Shih Ying Chen, Department of Health and Nutrition, Chia Nan University of Pharmacy and Science, No.60, Section. 1, Erren road, Rende District, Tainan City 71710 , Taiwan, ROC, Tel: 886-0905826630; Fax: 886-6-3663756;

E-mail: shihying@mail.cnu.edu.tw; osyc@ms48.hinet.net

Citation: Chen S. Y., et al. Anti-Proliferative and Apoptotic Effects of Polygonum Cuspidatum and its Bioactive Compound, Emodin, in Colorectal Carcinoma HT-29 cells. (2018) Int J Food Nutr Sci 5(1): 16- 24. 
Polygonum cuspidatum has been conventionally used as folk medicines in many countries for centuries. Traditionally, Polygonum cuspidatum has been used for the treatment of serious diseases such as asthma, cough, hypertension, and cancer ${ }^{[4]}$. The biological activity of Polygonum cuspidatum has been reported. For example, the ethanolic extracts of Polygonum cuspidatum have been described as displaying biological activity, having the potential to inhibit hepatitis virus (HBV) replication $^{[2]}$. and EBV lytic cycle ${ }^{[5]}$. In addition, this herb has been reported to contain many bioactive compounds such as anthra glycoside B, physcion, piceid, emodin and resveratrol. In addition, a previous study by the authors of this paper demonstrated that ethyl acetate sub fraction F3, extracted from Polygonum cuspidatum, and its major bioactive compound, emodin, exhibited significant inhibition of Epstein-Barr virus (EBV) ${ }^{[5]}$. Given that Polygonum cuspidatum can inhibit HBV and EBV, it may also have the potential to inhibit the proliferation of cancer cells. However, it remains unclear whether Polygonum cuspidatum exhibits an antiproliferative effect against cancer cells. Therefore, this study aims to determine the antiproliferative effect of Polygonum cuspidatum and its bioactive compound, emodin, on human colorectal carcinoma HT-29 cells and also to elucidate the possible mechanism action.

\section{Material and Methods}

\section{Material}

The root of Polygonum cuspidatum was collected from the SanDei-Men area in Pingtung County, Taiwan and verified by Prof. C. S. Kuoh. The specimen was deposited in the herbarium of the National Cheng Kung University, Tainan, Taiwan.
Sample Preparation: Ten grams of dried powder from the P. cuspidatum root was extracted three times in $100 \mathrm{~mL}$ of ethanol by refluxing at $85^{\circ} \mathrm{C}$ for $2 \mathrm{~h}$. After each extraction, the ethanol fraction was collected by filtration. The ethanol fractions were partitioned twice with hexane and water (10:10:1, v/v/v). The aqueous fractions were collected, concentrated under reduced pressure, and called EPC. Dried EPC (1 g) dissolved in $100 \mathrm{~mL}$ distilled water was partitioned with an equal volume of ethyl acetate (EtOAc). The EtOAc fractions were collected, concentrated under reduced pressure, and called EAPC. The EAPC soluble fraction was subjected to semi-preparative HPLC using a HYPERPREP C18 $(150 \times 10 \mathrm{~mm}$ i.d., $8 \mu \mathrm{m})$ column (Thermo Fisher, Waltham, MA, USA) and eluted with a mobile phase consisting of water (A) and methanol (B) for emodin preparation. Gradient elution was performed as follows: $30 \%-50 \%$ $\mathrm{B}$ in $0-15 \mathrm{~min}, 50 \%-90 \% \mathrm{~B}$ in $15-35 \mathrm{~min}$, and $95 \% \mathrm{~B}$ in $35-45 \mathrm{~min}$. The resulting residues were finally dissolved in dimethyl sulfoxide (DMSO) ${ }^{[2]}$. The vehicle control in this study was necessary because test samples were dissolved in DMSO (final concentration was $0.5 \%$ ).

\section{Identification by HPLC Analysis}

The components in the EAPC soluble fraction and separated emodin were further analyzed by high performance liquid chromatography (HPLC) using a Li Chrospher 100 RP-18e (250 $\times 4.6 \mathrm{~mm}$ i.d., $5 \mu \mathrm{m}$ ) column (Merck, Darmstadt, Germany). The mobile phase consisted of water (A) and methanol (B). Gradient elution was performed as follows: $30 \%-50 \% \mathrm{~B}$ in $0-15 \mathrm{~min}$, $50 \%-90 \% \mathrm{~B}$ in $15-35 \mathrm{~min}$, and $95 \% \mathrm{~B}$ in $35-45 \mathrm{~min}$. The flow rate was set at $1 \mathrm{~mL} / \mathrm{min}$. The identification of piceid, resveratrol, anthrglycoside B and emodin was carried out by comparing their retention times and characteristic spectra with those of authentic standards (Figure 1).

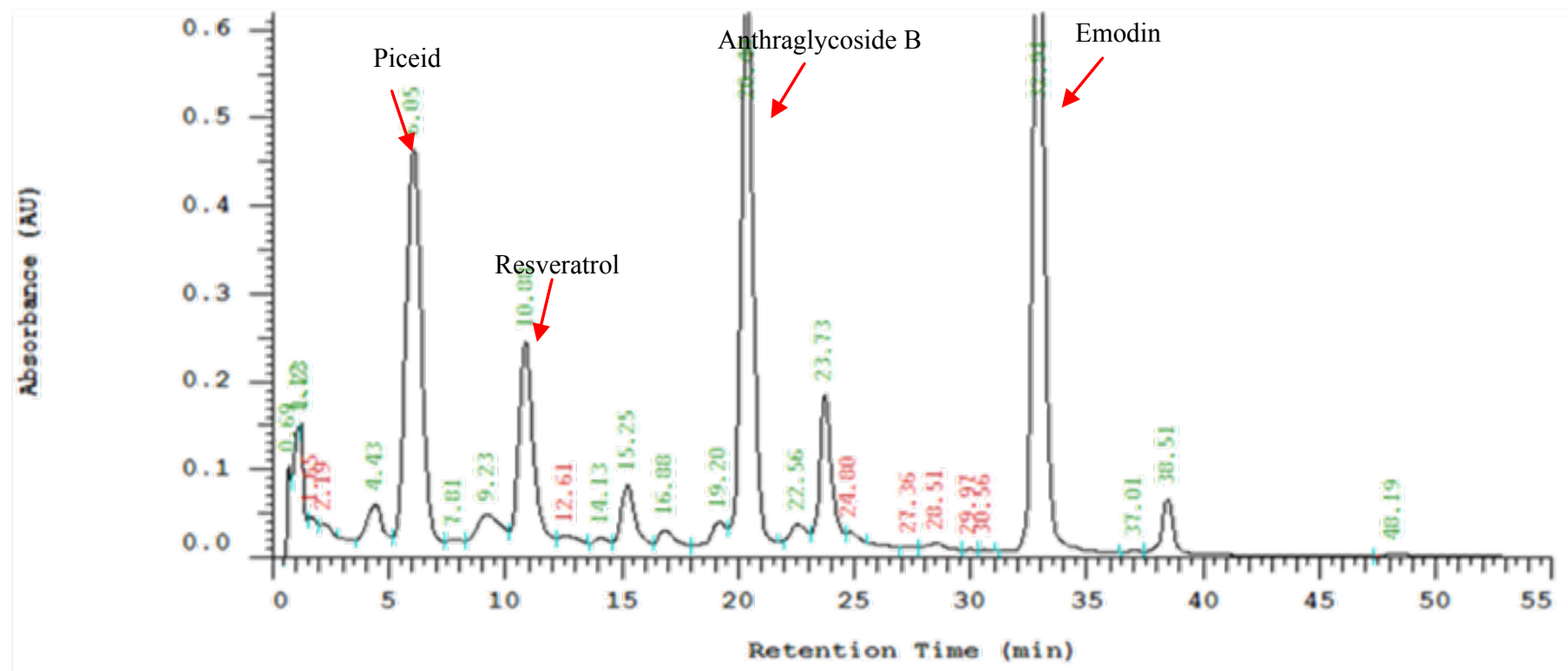




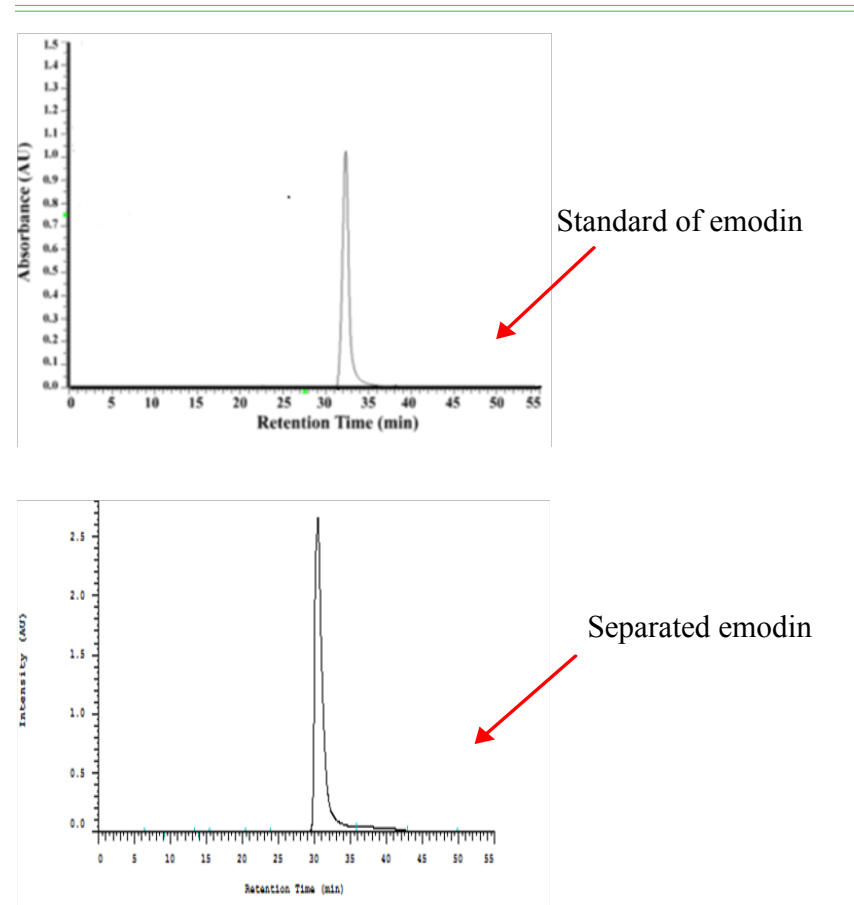

Figure1: HPLC Chromatograms and UV Spectra of the Ethyl acetate Sub fraction Isolated from Polygonum cuspidatum Root (A), Standard of Emodin (B) and Separated Emodin (C).

Note: Mobile phase: methanol-water (methanol: 0 - $15 \mathrm{~min}, 30 \%-$ $50 \%$; 15 - $35 \mathrm{~min}, 50 \%-90 \%$; $35-45 \mathrm{~min}, 95 \%$ ); flow rate: $1.0 \mathrm{~mL} /$ min; detection wavelength: $280 \mathrm{~nm}$.

\section{HT-29 Cell Viability Assay}

The tetrazolium dye colorimetric test (MTT test) was used to determine the viability of HT-29 cells. Cells were plated in 24-well flat-bottom plat at a density of $5 \times 10^{4}$ cells $/ \mathrm{mL}$ and grown. After 24, 48, $72 \mathrm{~h}$ incubation, cells were treated with or without test samples. After a period of incubation, $50 \mu \mathrm{L} 0.1 \%$ MTT solution was added and cells were incubated for a further $1 \mathrm{~h}$. Subsequently, the reaction was terminated and the plates were incubated for $30 \mathrm{~min}$ to solubilize the formazan dye by addition of dimethyl sulfoxide. The optical density of each well was determined at $570 \mathrm{~nm}$.

\section{Apoptosis Assay by Flow Cytometry}

The apoptosis of cells induced by the extract was assayed by treatment with Annexin V and PI double labeling according to the manufacturer's instruction (Biovision AnnexinV-FITC Apoptosis Detection Kit). Cells $\left(4 \times 10^{5}\right.$ cells $\left./ \mathrm{mL}\right)$ were incubated for $3,6,12,24$ and $48 \mathrm{~h}(3-48 \mathrm{~h})$ in the presence or absence of the test samples. Cells were centrifuged to remove the medium, washed with PBS, and stained with Annexin V and PI in binding buffer. The stained cells were determined using FAC Scan flow cytometry (Beckman Altra). Annexin $\mathrm{V}^{+} \mathrm{PI}^{-}$cells were considered as earlyapoptosis while Annexin $\mathrm{V}^{+} \mathrm{PI}^{+}$cells as late apoptosis ${ }^{[6]}$.

\section{Comet Assay}

Comet assay was determined and modified by the methods of Szeto et al. and Braz et a ${ }^{[1,4,27]}$. Each step was carried out under indirect light. Slides were coded and analyzed without knowledge of the identity of the sample. Volumes of 10 $\mu \mathrm{L}$ of cells $\left(1 \times 10^{6}\right.$ cells $\left./ \mathrm{mL}\right)$ treated with $3-48 \mathrm{~h}$ were added to $0.5 \%$ low melting point agarose, respectively, at $37^{\circ} \mathrm{C}$. The mixtures were layered onto slides precoated with $1.5 \%$ normal agarose, covered with a cover slip, and left for $5 \mathrm{~min}$ at $4{ }^{\circ} \mathrm{C}$ to solidify the agarose. Afterwards, the cover slips were carefully removed and the slides immersed in a lysis solution for $15 \mathrm{~min}$. Then, the slides were immersed in a freshly prepared alkaline buffer in a horizontal electrophoresis tank. After a 20 min DNA unwinding period, electrophoresis was conducted at $30 \mathrm{~V}$ and $300 \mathrm{~mA}$ for $20 \mathrm{~min}$. Following $10 \mathrm{~min}$ neutralization with 0.4 $\mathrm{M}$ tris (hydroxymethyl) amino methane (Tris, $\mathrm{pH} 7.5$ ), the slides were fixed in methanol, and stored at $4{ }^{\circ} \mathrm{C}$. Before analysis, the slides were stained with $10 \mu \mathrm{L}$ propidium iodide $(2.5 \mu \mathrm{g} / \mathrm{mL})$ and scored using a fluorescent microscope (Nikon, Tokyo, Japan) at $200 \times$ magnifications. Images from 100 "nucleoids" (20 - 30 from each of two replicate slides per sample) were analyzed using the Comet assay free software (Perceptive Instruments, Haverhill, Su Volk, UK). Tail moment and tail intensity were used to estimate DNA damage. As tail intensity (\% DNA tail) gave similar results, only tail moment values were presented.

Evaluation of Reactive Oxygen Species (ROS) in HT-29 Cells Intracellular ROS was estimated by using a fluorescent probe, DCFH-DA ${ }^{[7]}$. To determine the generation of ROS in HT-29 cells, DCFH-DA was used when it penetrates the cell membranes and was hydrolyzed by intracellular esterase to form dichlorofluorescin $(\mathrm{DCFH})$. HT-29 cells $\left(5 \times 10^{4}\right.$ cells $\left./ \mathrm{mL}\right)$ were pretreated with DCFH-DA $(50 \mu \mathrm{M})$ for $30 \mathrm{~min}$, and then samples were added to the medium. After incubation at $37{ }^{\circ} \mathrm{C}$ for 3 - $48 \mathrm{~h}$, ROS produced from intracellular stress was detected using a Bio-Tek FLx800 micro plate fluorescence reader (Fisher Scientific) with excitation and emission wavelengths of 480 and $530 \mathrm{~nm}$, respectively.

\section{Measurement of Caspase-3 Activity Determination}

Activity of caspase- 3 was determined by using fluoro metric assay kits (Promega-Corporation, Madison, WI, USA) according to the manufacturer's protocol. In brief, the cells $\left(5 \times 10^{4}\right.$ cells $\left./ \mathrm{mL}\right)$ were plated in 24 well. After $24 \mathrm{~h}$ incubation; cells were treated with the test samples for 3-48 h. The cells were removed and added $25 \mu \mathrm{L}$ Caspase-Glo ${ }^{\circledR} 3 / 7 /$ kit. After incubation in $5 \% \mathrm{CO}_{2} / 95 \%$ air at $37^{\circ} \mathrm{C}$ for $1 \mathrm{~h}$, the activity was measured using a fluorophotometer (FLx 800, BioTek ${ }^{\circledR}$ ) with luminol. Data were expressed as percentage of the control, and the control group was designed as $100 \%{ }^{[7]}$.

\section{Preparation of Nuclear Extracts}

Nuclear extracts from treated cells were prepared with a nuclear extract kit (Panomics Inc., Redwood City, CA, USA) according to the user manual. Protein concentrations were determined by the Bradford assay (Bio-Rad, Richmond, CA, USA). Briefly, HT-29 cells were washed with cold PBS for two times, scraped into PBS with $1 \mathrm{mM}$ phenymethylsulphonyfluoride (PMSF) and pelleted by centrifugation $(500 \mathrm{~g})$ at $4{ }^{\circ} \mathrm{C}$ for 10 min. Cell pellets were resuspended in buffer A (20 mM HEPES, pH 7.9, $10 \mathrm{mM} \mathrm{KCl}, 0.1 \mathrm{mM}$ ethylenediamine tetra acetic acid (EDTA), $1 \mathrm{mM}$ ethyleneglycol tetra acetic acid (EGTA), $1 \mathrm{mM}$ sodium orthovanadate, $50 \mathrm{mM} \mathrm{NaF}, 1 \mathrm{mM}$ PMSF, $20 \mathrm{mg} / \mathrm{mL}$ aprotinin, $20 \mathrm{mg} / \mathrm{mL}$ antipain, $20 \mathrm{mg} / \mathrm{mL}$ leupeptin and $10 \mathrm{mg} /$ $\mathrm{mL}$ pepstatin $\mathrm{A}$ ) and incubated on ice for $10 \mathrm{~min}$. Nonidet $\mathrm{P}-40$ was added to a final concentration of $0.2 \%$ and the cell suspension was passed through a 26 -gauge needle to break open the 
cells. After centrifugation $(12,000 \mathrm{~g}$, in a micro centrifuge) at $4^{\circ} \mathrm{C}$ for $1 \mathrm{~min}$, supernatants were collected as cytoplasmic extracts, and the pellets (crude nuclei) were resuspended in buffer B (20 mM HEPES, pH 7.9, 0.4 M NaCl, 1 mM EDTA, $1 \mathrm{mM}$ EGTA, $1 \mathrm{mM}$ dithiothreitol (DTT), $1 \mathrm{mM}$ sodium orthovanadate, $50 \mathrm{mM} \mathrm{NaF}$ and the same protease inhibitors as in buffer A). After incubating for $60 \mathrm{~min}$ on ice, insoluble materials were pelleted by centrifugation $(15,000 \mathrm{~g})$ at $4^{\circ} \mathrm{C}$ for $10 \mathrm{~min}$ and supernatants were collected as nuclear extracts.

\section{Assays for NFkB and AP-1 Activation}

Nuclear extracts were obtained, according to Nuclear Extraction Kit User Manual, Panomics, Inc. Briefly, confluent cells in 10-cm-diameter dishes were resuspended in $200 \mu \mathrm{L}$ of buffer (10 mM HEPES, pH 7.9, $10 \mathrm{mM} \mathrm{KCl,} 1 \mathrm{mM}$ DTT, 0.5 mM EDTA, $0.5 \mathrm{mM}$ PMSF), and lysed with $12.5 \mu \mathrm{L}$ of $10 \%$ NP-40. The nuclear fractions were harvested by centrifugation at $14,000 \mathrm{~g}$, at $4^{\circ} \mathrm{C}$ for $2 \mathrm{~min}$. The supernatant was used as the source of the cytosolic proteins. The nuclear pellets were resuspended in $50 \mu \mathrm{L}$ of extraction buffer (20 mM HEPES, pH 7.9, $400 \mathrm{mM} \mathrm{NaCl}, 1 \mathrm{mM}$ DTT, $1 \mathrm{mM}$ PMSF, $1 \mathrm{mM}$ EDTA, 1\% NP-40), and then incubated on ice, for $10 \mathrm{~min}$. The nuclear debris was removed by centrifugation at $14,000 \mathrm{~g}$ at $4^{\circ} \mathrm{C}$ for 10 min, and the supernatant was used as the source of the nuclear proteins. The activation and subsequent translocation of $\mathrm{NF \kappa B}$ and AP-1 to the nucleus was determined by measuring NF- $\kappa \mathrm{B}$ and AP-1 protein levels in the nuclear extracts, by Western blot analysis.

\section{Western Blot Analysis}

Western blot analysis was performed as described previously ${ }^{[7]}$. Proteins were separated using SDS-PAGE and electrically transferred to a NC membrane (Pall, New York, NY, USA). After that, the membranes were blocked with TBST $(50 \mathrm{mM}$ Tris-HCl, pH 7.4, 0.15 M NaCl, 0.1\% Tween-20) containing $5 \%$ BSA (Sigma, St. Louis, MO, USA) for $2 \mathrm{~h}$. Then the membranes were incubated with primary antibodies against $\mathrm{NF} \kappa \mathrm{B}$, c-jun, $p$-c-jun, c-fos, $p$-c-fos, poly ADP-ribose protein (PARP), and caspase- 3 protein diluted at $1: 1000$ at $4{ }^{\circ} \mathrm{C}$ over night. After washing with TBST for three times, the membranes were incubated with goat anti-rabbit IgG labeled with horse radish peroxidase (Santa Cruz, Dallas, TX, USA) diluted at 1:2000 at room temperature for $2 \mathrm{~h}$. Blots were developed using an ECL plus kit (Amersham Bioscience, Aylesbury, UK), exposed to Kodak auto radiographic films and quantified using Image $\mathrm{J}$ software.

\section{Statistical Analysis}

The results are expressed as mean \pm standard deviation (SD), and ANOVA was conducted by using the SPSS software (version 12.0; SPSS, Chicago, IL, USA). When a significant F ratio was obtained $(p<0.05)$ a post hoc analysis was conducted between groups by using a multiple comparison procedure with a Dunnett's test. Statistical significance was accepted at a level of $p<0.05$.

\section{Results}

HPLC Chromatograms and UV Spectra of EAPC and Emodin

Figure 1 shows that the identification of the bioactive compounds of EAPC was conducted by HPLC as compared to

their retention times and characteristic spectra with an authentic standard. The major compounds detected in EAPC were piceid, resveratrol, anthrglycoside $\mathrm{B}$, and emodin. By calculating from the standard curves of piceid, resveratrol, anthrglycoside B, and emodin, the content of piceid, resveratrol, anthrglycoside B, and emodin are 97, 50, 147, $231 \mathrm{mg} / \mathrm{g}$ of EAPC, respectively. Apparently, emodin is the main constituent present in EAPC. This result is in agreement with our previous study ${ }^{[5]}$ which showed that emodin is a major compound present in Polygonum cuspidatum root. Therefore, emodin was selected as a reference compound for the following tests.

\section{Effects of EAPC and Emodin on Cell Viability and Apoptosis in HT-29 Cell}

The cytotoxicity of HT-29 cell growth after 72 h treatment with different concentrations of EAPC and emodin was determined by MTT assay. The data in Figure 2 show that EAPC and emodin inhibit proliferation of HT-29 cells in a time and concentration dependent manner. The concentration of EAPC and emodin that induced a $50 \%$ inhibition $\left(\mathrm{IC}_{50}\right)$ of HT-29 cell growth as compared to controls was 141.4 and $73.0 \mu \mathrm{g} / \mathrm{mL}$, respectively. Given that EAPC and emodin are potent inhibitors of HT-29 cell growth, we further examined whether EAPC and emodin induce apoptosis in HT-29 cells. The apoptosis induced by EAPC and emodin on HT-29 cells was determined by flow cytomety as shown in Figure 3 . The data show the effect of EAPC and emodin on apoptosis in HT-29 cells, revealing dose results showing a dose-dependent increase in apoptosis in EAPC- and emodin-treated cells. For example, under treatment with $25,50,100 \mu \mathrm{g} / \mathrm{mL}$ of emodin for $12 \mathrm{~h}$, the percentages of early apoptosis cells plus the late apoptosis were 2.50, 53.41 and $92.94 \%$, respectively. For EAPC, the percentages of early apoptosis cells plus the late apoptosis were $0.45,0.49,0.78,5.38$, and $22.57 \%$ for $25,50,100,200$ and $400 \mu \mathrm{g} / \mathrm{mL}$, respectively. These results show a significant increase in apoptosis and decrease in survival in HT-29 cells exposed to EAPC and emodin.

A
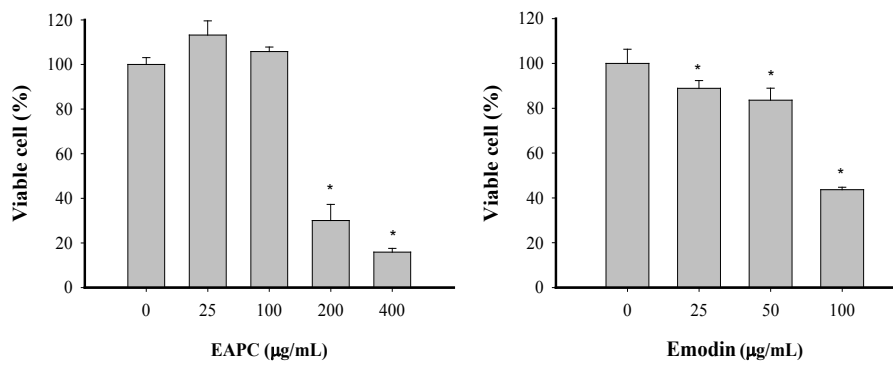

Figure 2: Effects of EAPC (A) and Emodin (B) on HT-29 Cells Viability. HT-29 Cells $\left(5 \times 10^{4}\right.$ cells $\left./ \mathrm{mL}\right)$ were Treated with Test Samples.

Note: Cell numbers and viability were monitored by MTT assay after $72 \mathrm{~h}$ of treatment. Experiments were done in triplicates. Values are expressed as the mean $\pm \mathrm{SD}$. Dennett's test for multiple comparison, ${ }^{*} p$ $<0.05 \mathrm{vs} 0(\mu \mathrm{g} / \mathrm{mL})$. 
Citation: Chen, S. Y., et al. Anti-Proliferative and Apoptotic Effects of Polygonum Cuspidatum and its Bioactive Compound, Emodin, in Colorectal Carcinoma HT-29 cells. (2018) Int J Food Nutr Sci 5(1): 16-24.
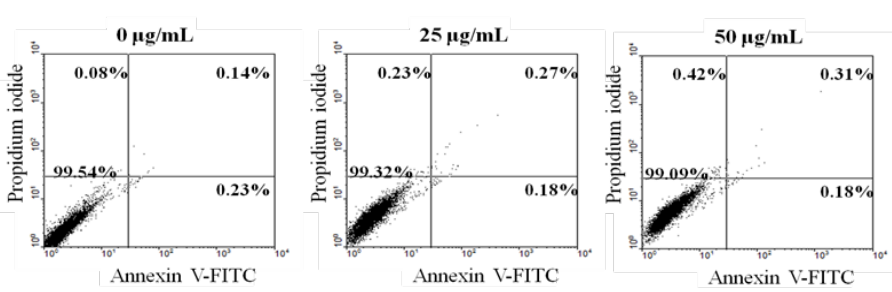

A
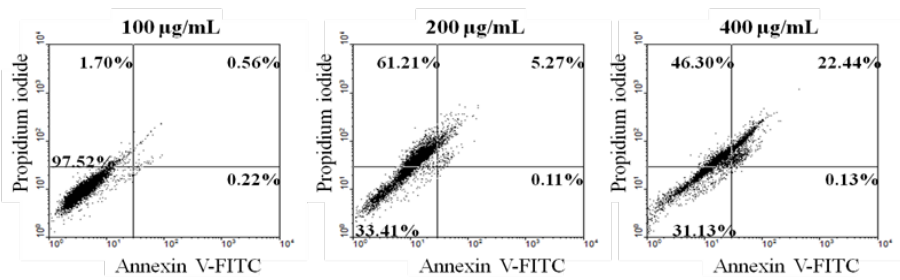

B
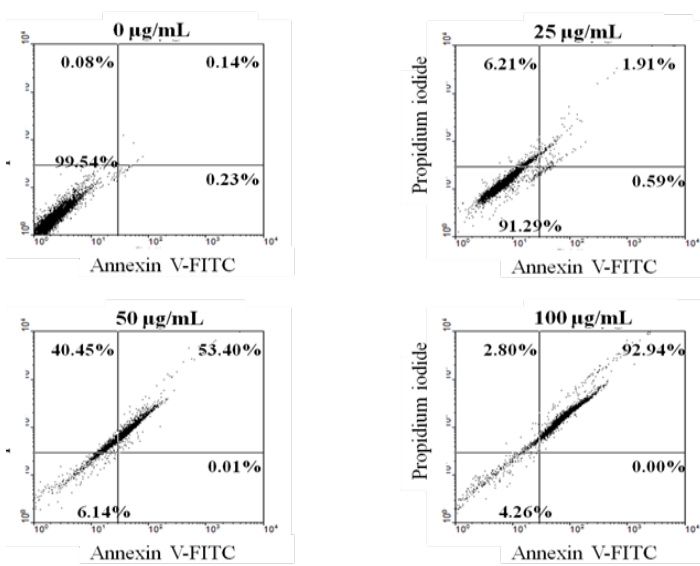

Figure 3: EAPC (A) and Emodin (B) Induces Apoptosis in HT-29 Cells $\left(4 \times 10^{5}\right.$ cells $\left./ \mathrm{mL}\right)$ for $12 \mathrm{~h}$. Note: Experiments were done in triplicates.

Genotoxicity of EAPC and Emodin on DNA Strand Breakage in HT-29 Cell

The comet assay is widely used for measuring DNA strand breaks in eukaryotic cells. In order to understand the genotoxicity of EAPC and emodin on HT-29, comet assay, which is a sensitive technique for measuring DNA strand breaks in eukaryotic cells, was used to determine the damaging effect of EAPC and emodin on DNA. Figure 4 shows that treatment with EAPC and emodin ranged from $25-400$ and $25-100 \mu \mathrm{g} / \mathrm{mL}$, respectively, for $24 \mathrm{~h}$ incubation significantly increased damage to the DNA strand, compared to the control cells. When HT-29 cells were incubated with $200 \mu \mathrm{g} / \mathrm{mL}$ of EAPC, DNA damage increased, with a value of $75.6 \%$ above that in control cells. Treatment of HT-29 cells with $100 \mu \mathrm{g} / \mathrm{mL}$ of emodin for $24 \mathrm{~h}$ induced on increment of $67.8 \%$ with respect to the control. These results indicate that EAPC and emodin caused a pronounced damage to HT-29 cells under the tested concentrations. Obviously, EAPC and emodin exerted genotoxicity on HT-29 cells under the tested concentrations.
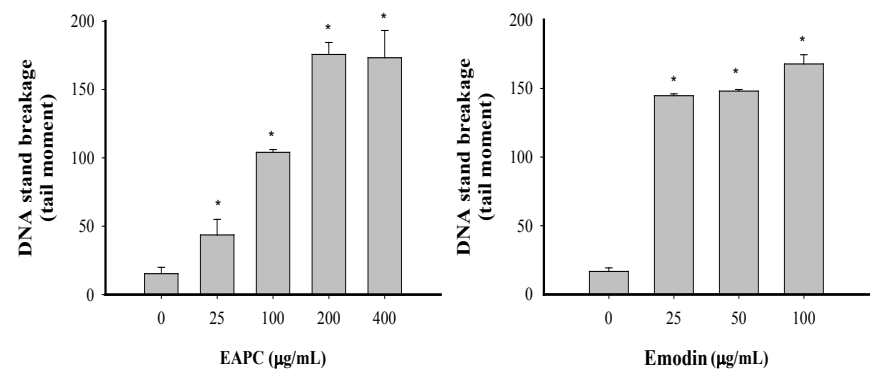

Figure 4: Genotoxicity of EAPC (A) and Emodin (B) on DNA Strand Breakage in Treated HT-29 Cells $\left(1 \times 10^{6}\right.$ cells $\left./ \mathrm{mL}\right)$ for $24 \mathrm{~h}$.

Note: Tail moment $=$ percent of DNA in the tail $\times$ tail length $(\mu \mathrm{m})$. Experiments were done in triplicates. Values are expressed as the mean \pm SD. Dennett's test for multiple comparison, ${ }^{*} \mathrm{p}<0.05 \mathrm{vs} 0(\mu \mathrm{g} / \mathrm{mL})$.

\section{EAPC and Emodin Induce ROS Accumulation in HT-29 Cell}

Increased apoptosis and DNA damage are often associated with ROS accumulation, which can be detected by the ROS-sensitive fluorescence dye, $\mathrm{H}_{2} \mathrm{DCFDA}^{[3]}$. In addition, ROS production is implicated in apoptosis and has been described as an early event ${ }^{[8]}$. Thus, HT-29 cells were co-incubated with
EAPC and emodin for only $6 \mathrm{~h}$ before determination of ROS accumulation in HT-29 cells. Figure 5 shows the effect of EAPC and emodin on inducing ROS accumulation in HT-29 cells. The treatment of HT-29 cells with emodin in a range of $25-100 \mu \mathrm{g} /$ $\mathrm{mL}$ for $6 \mathrm{~h}$ led to increased ROS accumulation in a concentration-dependent manner, whereas a mild increase in ROS accumulation was observed after the addition of EAPC at $25-400$ $\mu \mathrm{g} / \mathrm{mL}$, indicating that EAPC and emodin induce ROS accumulation in HT-29 cells at the tested concentration.
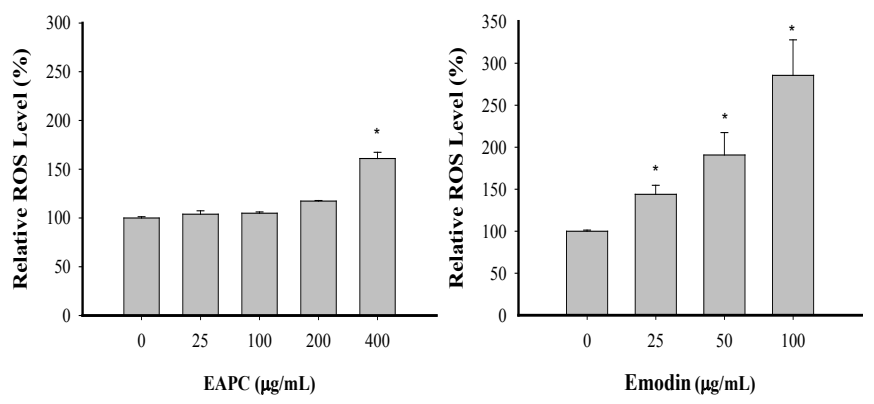

Figure 5: EAPC (A) and Emodin (B)Induces Production of ROS in HT29 Cells $\left(5 \times 10^{4}\right.$ cells $\left./ \mathrm{mL}\right)$ for $12 \mathrm{~h}$.

Note: Experiments were done in triplicates. Values are expressed as the mean \pm SD. Dennett's test for multiple comparison, $* \mathrm{p}<0.05$ vs $0(\mu \mathrm{g} / \mathrm{mL})$.

\section{Effect of EAPC and Emodin on Caspase-3 and PARP Ex- pression in HT-29 Cell}

Caspases are a family of cysteine proteases that play an important role in apoptosis. In addition, activation of caspase-3 results in the degradation of the downstream protein, poly ADP-ribose protein (PARP), a hallmark of apoptosis. To further investigate whether EAPC and emodin affect apoptosis in HT-29 cells, through activation of a caspase pathway, this study identifies caspase- 3 activation and PARP protein expression as markers of apoptosis. The results show that treating HT-29 cells with different concentrations of EAPC and emodin did not displayed any effects on activation of caspase- 3 and PARP cleavage (data not shown), suggesting that the cytotoxic effects of EAPC and emodin on HT-29 cells by inducing apoptosis are not associated with activation of a caspase pathway. 


\section{Effect of EAPC and Emodin on NFKB Expression in HT-29 Cell}

$\mathrm{NF \kappa B}$ is a potent transcriptional factor that regulates the expression of genes that control cell proliferation and cell survival ${ }^{[3]}$. Therefore, the regulation of NFKB activity by EAPC and emodin is measured by Western blotting in cell nuclear. As shown in Figure 6, emodin treatment decreases the NFאB activity in HT-29 cells; however, EAPC ranging from $25-200 \mu \mathrm{g} / \mathrm{mL}$ does not show not any effect on NFkB activity as compared to the control.

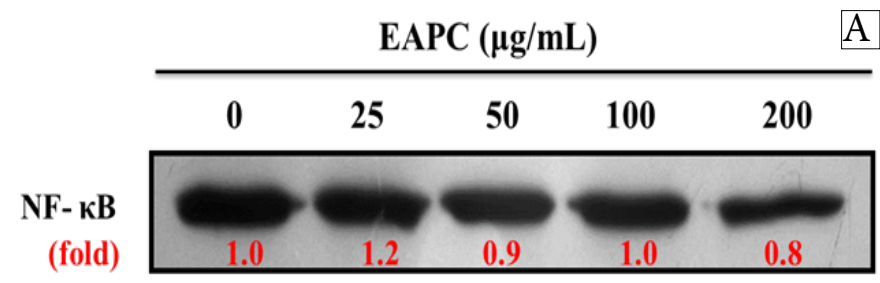

Lamin B
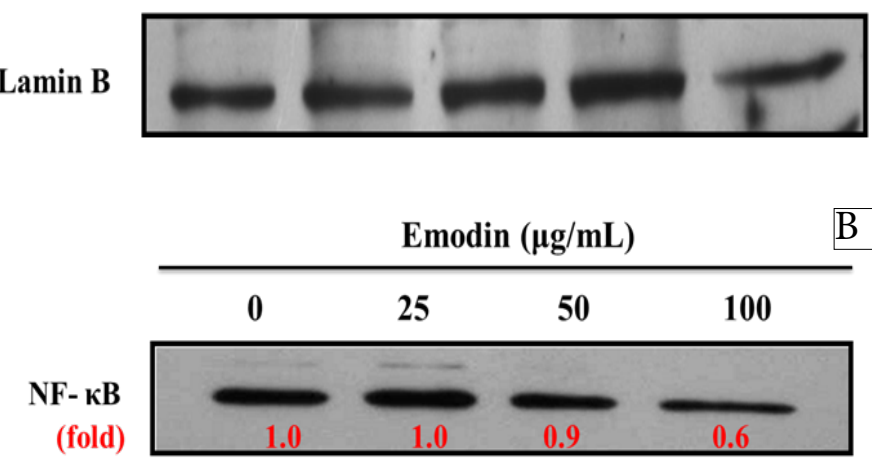

Lamin B

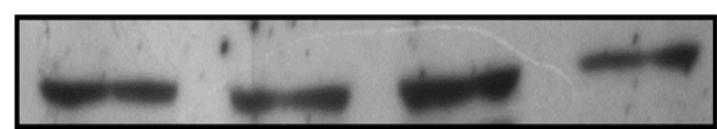

Figure 6: Effect of EAPC (A) and Emodin (B) for $12 \mathrm{~h}$ on NFkB Expression in HT-29Cells $\left(5 \times 10^{4}\right.$ cells $\left./ \mathrm{mL}\right)$.

Note: Experiments were done in triplicates.

\section{Effect of EAPC and Emodin on Activator Protein-1 Expres- sion in HT-29 Cell}

Activator protein-1 (AP-1), which consists of Jun (c-jun, Jun B, Jun D), Fos (c-fos, Fra-1, fra-2 and Fos B) and Atf (activating transcription factor) sub-families is involved in the regulation of host immune response and plays a major role in the activation of numerous genes involved in cell differentiation, proliferation, apoptosis, immune responses, etc ${ }^{[9]}$. To assess whether the antiproliferative effects of EAPC and emodin on HT-29 cells are related to AP-1, the activation of AP-1 was measured. According to the results in Figure 7, the phosphorylated levels of c-jun and c-fos increased with increasing concentrations of emodin, however, EAPC did not affect c-jun and $\mathrm{c}$-fos as compared to the control. These observations imply that emodin induced an increase in the nuclear c-jun and c-fos levels, which could be related to the results of AP-1 DNA binding activity $^{[10]}$.

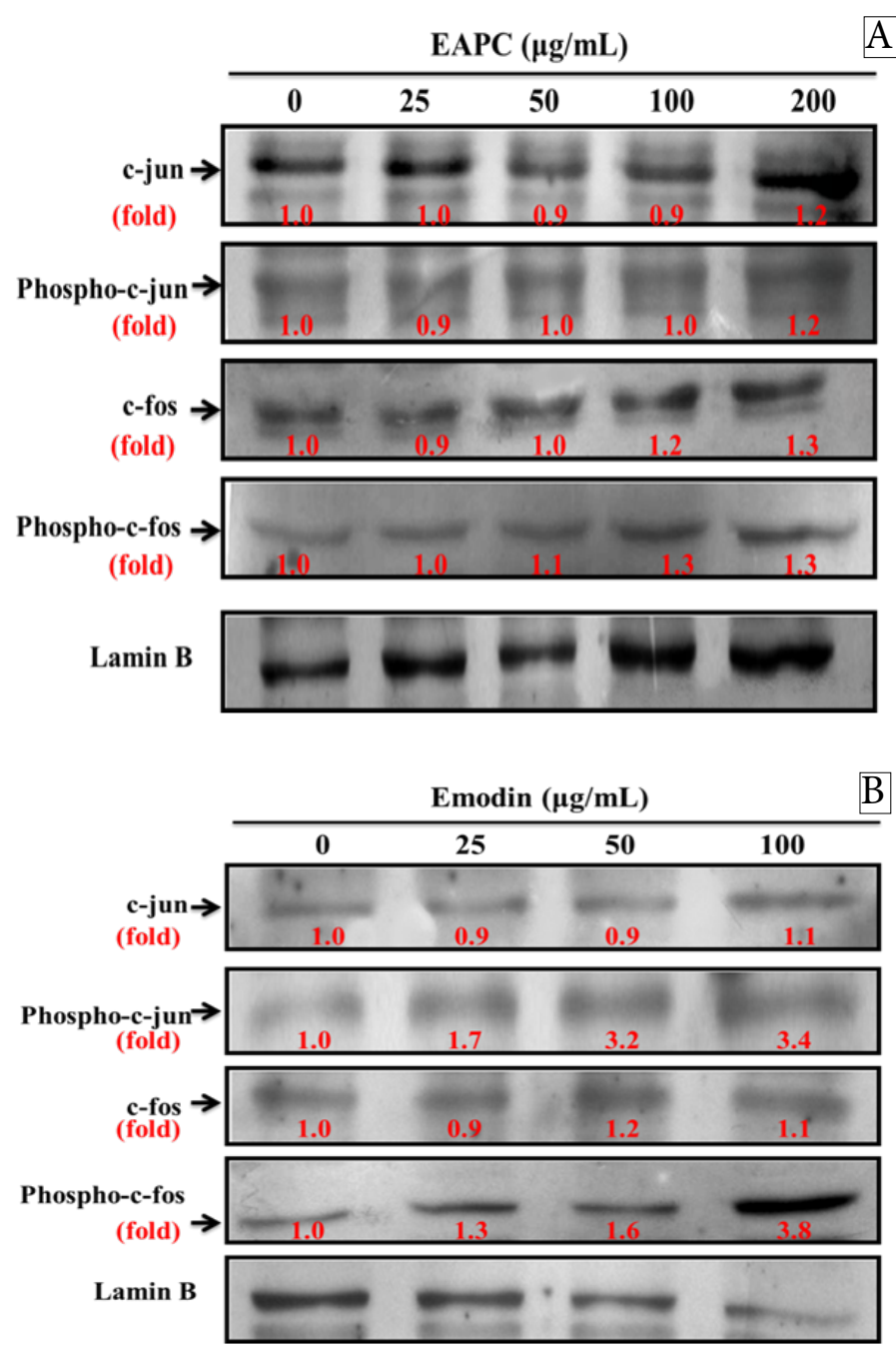

Figure 7: Effect of EAPC (A) and Emodin (B) for $6 \mathrm{~h}$ on Activator Protein-1 (AP-1) Expression in HT-29 Cells $\left(5 \times 10^{4}\right.$ cells $\left./ \mathrm{mL}\right)$.

Note: Experiments were done in triplicates.

\section{Discussion}

Chemoprevention is defined as the use of agents to inhibit, reverse or retard carcinogenesis ${ }^{[11]}$. Most chemo preventive agents, derived from natural products, are plant extracts subdivided into blocking agents, which retard or inhibit the initiation step, and suppressing agents, which suppress malignant cell proliferation during the promotion and progression steps of carcinogenesis ${ }^{[12]}$. According to the data from Figure 2(A), EAPC significantly inhibited HT-29 cell growth. Of special note, emodin, ubiquitously present in plants, which was isolated as a major compound from EAPC, demonstrated effective cytotoxic effect on HT-29 cell growth. Clearly, EAPC and emodin demonstrated antiproliferative activity on HT-29 cells; however, the molecular mechanisms of EAPC and emodin which induced apoptosis have not been elucidated. Therefore, subsequent experiments were conducted.

Externalization of plasma membrane phosphatidylserine is one indicator of apoptosis. Therefore, cytofluorimetric analysis of annexin V-FITC/PI double labeled HT-29 cells was conducted to analyze phosphatidylserine externalization, which is an event occurring in the early phase of apoptotic cell death when a cell membrane is damaged ${ }^{[13]}$. The dot plot of flow cy- 
Citation: Chen, S. Y., et al. Anti-Proliferative and Apoptotic Effects of Polygonum Cuspidatum and its Bioactive Compound, Emodin, in Colorectal Carcinoma HT-29 cells. (2018) Int J Food Nutr Sci 5(1): 16-24.

tometric data represents each stage of the treated cell line, including viable $\left(\mathrm{V}^{-} \mathrm{P}^{-}\right)$, early-stage apoptosis $\left(\mathrm{V}^{+} \mathrm{P}^{-}\right)$, late-stage apoptosis $\left(\mathrm{V}^{+} \mathrm{P}^{+}\right)$and necrosis $\left(\mathrm{V}^{-} \mathrm{P}^{+}\right)^{[14]}$. For the untreated cells, $99.54 \%$ cells were viable; however, the percentage of total apoptotic cells in EAPC and emodin increased in a dose-dependent manner (ranging from, 0.45 to $22.57 \%$ and $2.5 \%$ to $92.94 \%$, respectively), confirming that the mode of cell death was apoptosis. It is worth noting that after $12 \mathrm{~h}$ exposure the number of early apoptotic cells decreased, but with significant migration of cells to the late stage of apoptosis. Obviously, EAPC and emodin at tested concentrations induced more late-state apoptosis than the induction of early-state apoptosis. This finding indicates that EAPC and emodin allowed the translocation of phosphatidylserine to occur and hence induced apoptotic induction in HT-29 cells $^{[15]}$. These results show that the annexin V/PI double staining assay confirmed that EAPC and emodin induced apoptosis in HT-29 cells.

Many techniques have been investigated to measure DNA damage, either by measurement of lesions or at the genomic, transcriptomic and enzymatic levels ${ }^{[16]}$. Among these, the comet assay is widely used as an index of the extent of DNA damage. According to the results from Figure 4, EAPC and emodin have the potential to induce DNA strand breaks in HT-29 cells, which may correspond either to direct DNA damage or to the induction of non-specific endonuclease activity ${ }^{[16]}$. Many studies have shown that fragmentation of DNA is an event that characterizes apoptosis ${ }^{[17]}$. Therefore, our data show that the DNA strand breaks observed in HT-29 cells exposed to EAPC and emodin might be lead to apoptosis of HT-29 cells.

ROS are well known as mediators of the apoptosis signaling pathway. Higher levels of ROS in cells induce not only cell death, but also lead to DNA damage and genomic instability $^{[9]}$. In other words, ROS play an important role in the induction of apoptosis. It is therefore necessary to understand whether the effects of EAPC and emodin stimulated ROS generation in HT-29 cells. Many studies have noted that apoptosis can be induced by ROS, leading to pathological cell death ${ }^{[18]}$. Thus, enhancement of ROS generation causes lipid per oxidation in cell membranes, DNA damage, and a decrease in the mitochondrial trans membrane potential, which can lead to cell death/injury ${ }^{[18]}$. The present study shows that EAPC and emodin demonstrated pro-oxidant action on HT-29 cells under the tested concentrations, accompanied by increases in ROS, compared to untreated cells. According to the results from Figures 2 and 5, the increase in ROS generation appeared in parallel with the decrease in HT29 cell growth under treatment with EAPC and emodin. These observations suggest that increased levels of ROS generated by EAPC and emodin during the oxidative stress period are efficiently harmful to HT-29 cells pretreated with EAPC and emodin, leading to cell death/injury. In addition, the results show that the generation of ROS (Figure 5) was enhanced by EAPC and emodin, resulting in DNA damage (Figure 4). This may contribute to DNA instability, and thereby lead to cell death. Many studies have reported that apoptosis induced by polyphenolic-rich extracts is associated with the increase of ROS generation $^{[19,20]}$. In other words, the generation of ROS is closely linked to apoptosis. Therefore, without direct ROS scavenging, EAPC and emodin demonstrated significant anti-proliferation of HT-29 cells through their pro-oxidant activity and contribution to oxidative stress, which in turn leads to cell death. This result is in agreement with the report of Droge ${ }^{[21]}$ who noted that chemopreventors induce apoptosis in part with the induction of ROS generation.

Accumulating evidence shows that NFkB activation is linked with tumor cell transformation and proliferation. As a transcriptional factor, NFKB often enhances cell growth in human cancer cells ${ }^{[22]}$. In an inactive state, $\mathrm{NF \kappa B}$ is sequestered and inactivated in cytoplasm by binding to $\mathrm{I} \kappa \mathrm{B}$. Activation of the $\mathrm{NF} \kappa \mathrm{B}$ pathway is mediated by the activation of the I $\kappa \mathrm{B}$ kinase complex (IKK), which leads to the phosphorylation and degradation of $\mathrm{I} \kappa \mathrm{B}$, subsequently causing to nuclear translocation of $\mathrm{NF} \kappa \mathrm{B}$ and binding to a specific DNA consensus sequence, which results in the transcriptional activation of $\mathrm{NF} \kappa \mathrm{B}$ regulated genes involved in antiapoptosis (e. g., Bcl-2 and Bcl- $\mathrm{X}_{\mathrm{L}}$ ), proliferation (COX-2 and cyclin D1), angiogenesis (e.g., VEGF) and metastasis (e.g., MMP-9 ${ }^{[10]}$. In other words, NFאB is a potent transcriptional factor that regulates the expression of genes that control cell proliferation and cell survival ${ }^{[3]}$. Our results demonstrate that after treating the cells with emodin, the levels of $\mathrm{NF} \kappa \mathrm{B}$ reduce, implying that emodin mediates its anticancer activity through the NFKB pathway ${ }^{[18]}$. AP-1 has been implicated to play an important role in the regulation of numerous genes involved in the function and development of the immune system, cell differentiation, proliferation, apoptosis, etc. According to the results from Figure 7, emodin induced and enhanced in the nuclear c-Jun levels, which could be related with the results of AP-1 DNA-binding activity ${ }^{[10]}$. In other words, emodin has a remarkably promotive effect on c-Jun levels, which accounts for its apoptotic responses in HT-29 cells ${ }^{[22]}$. In this study, NFкB and AP-1 are investigated as emodin targets because of the crucial role of $\mathrm{NF \kappa B}$ and $\mathrm{AP}-1$ in cell survival and proliferation. The results obtained indicate that emodin inhibited the $\mathrm{NF} \kappa \mathrm{B}$ activity and activated AP-1 binding by the inducing of c-jun nuclear translocation, indicating that JNK is an important mediator in emodin induced cell death ${ }^{[10]}$. Moreover, these results further confirm that emodin is an effective suppressor of the proliferation pathway and an inducer of apoptosis in HT-29 cells.

Emodin, belonging to the group of natural phenolic compounds, is a natural anthraquinone derivative. Traditionally, emodin is widely used as a mild laxative. In addition, many studies have shown that emodin possesses many biological activities, including antioxidant, antibacterial, antiviral, and antifungal properties ${ }^{[5]}$. Recent reports have noted that emodin has great potential due to anticancer activities against different cancers, including Hela cells, human bronchial epithelial cells and lung squamous carcinoma cells ${ }^{[23,24]}$. The present work observed the antiproliferative activity of emodin on human colorectal carcinoma HT-29 cells. In addition, EAPC and emodin showed similar trends in their antiproliferative activity in HT-29 cells. Thus, we suggest that emodin is a major compound that inhibits HT-29 cell growth. On the other hand, emodin demonstrated significant induction of ROS accumulation, inhibition of $\mathrm{NF \kappa B}$, and enhancement of AP-1 activity. However, EAPC showed mild induction of ROS accumulation and no effect on the activity of NFKB and AP-1. Apart from these findings, based on HPLC analysis there are other peaks present in EAPC, along with emodin, piceid, resveratrol, and anthrglycoside B, suggesting that other uncharacterized bioactive compounds may be present in EAPC. Many studies have reported that flavonoids and phenolic compounds are strong antioxidants under in vitro conditions in 
the presence of metal ions which can act as pro-oxidants ${ }^{[25]}$. In addition, whether or not phenolic compounds can react with other components of cell culture, the overall effect on cells, whether antioxidative or pro-oxidative, is strongly dependent on the composition of the medium ${ }^{[25]}$. In other words, compounds with antioxidant activity may exhibit pro-oxidant behavior under certain conditions ${ }^{[26]}$. Therefore, we speculate that these bioactive compounds, along with emodin, present in EAPC ${ }^{[27,33]}$ may render effects that could reduce the pro-oxidant action of EAPC by a direct or a synergistic action and are therefore responsible for the effects of EAPC on ROS accumulation and on the activities of NFKB and AP-1.

\section{Conclusions}

To our best knowledge, this study is the first to investigate the antiproliferative effects of EAPC on HT-29 cells. The possible mechanism for its effect involves ROS generation after EAPC exposure in HT-29 cells, which create oxidative bursts and lead to apoptosis of HT-29 cells. In addition, emodin enhanced ROS accumulation and exhibited a strong regulation of cell signaling pathways including a down regulation of $\mathrm{NF} \kappa \mathrm{B}$ and up regulation of AP-1 transcriptional factors, thereby leading to antiproliferation and apoptosis induction. Therefore, the inhibition of HT-29 cell proliferation could be related to the bioactive constituents present in EAPC. This evidence suggests that EAPC and emodin could be considered as therapeutic agents for the treatment of colorectal cancer. However, scientific trials in vivo should be conducted to validate the relevance of these results.

\section{Disclosure Statement}

The authors declare no conflicts of interest.

Funding: This work was supported by research grants NSC1002320-B-041-004-MY3 and MOST 104-2320-B-041-002 from the National Science Council, Taiwan.

\section{References}

1. Division of Cancer Prevention and Control, Centers for Disease Control and Prevention. (2017) Colorectal (Colon) Cancer.

Pubmed | Crossref $\mid$ Others

2. Gallaher, D.D., Trudo, S. P. Chapter 37 - Nutrition and Colon Cancer. (2017) Nutrition in the Prevention and Treatment of Disease (Fourth Edition) 787-807.

Pubmed | Crossref | Others

3. Li, B., Wang, C.Z., He, T.C., et al.. "Antioxidants Potentiate American Ginseng-Induced Killing of Colorectal Cancer Cells". (2010) Cancer Lett 289(1): 62-70.

Pubmed | Crossref| Others

4. Yi, T., Zhang, H., Cai, Z. Analysis of Rhizoma Polygoni cuspidati by HPLC and HPLC-ESI/MS. (2007) Phytochem Anal 18(5): 387-392. Pubmed $\mid$ Crossref $\mid$ Others

5. Yiu, C.Y., Chen, S.Y., Huang, C.W., et al. "Inhibitory Effects of Polygonum cuspidatum on the Epstein-Barr Virus Lytic Cycle".(2011) J Food Drug Anal, Vol. 19, pp. 107-113.

Pubmed | Crossref | Others

6. Idris, A., Zulkipli, I.N., Zulhilmi, N.R., et al. "Melastoma malabathricum Ethyl Acetate Fraction Induces Secondary Necrosis in Human Breast and Lung Cancer Cell Lines". (2017) Pharmacogn Mag 13(3): S688-S692.

Pubmed | Crossref $\mid$ Others

7. Chen, Z.T., Chu, H.L., Chyau, C.C., et al. "Protective Effects of Sweet Orange (Citrus Sinensis) Peel and Their Bioactive Compounds on Oxidative Stress". (2012) Food Chemi 135(4): 2119-2127.

Pubmed |Crossref|Others

8. Juan, M.E., Wenzel, U., Daniel, H., et al. "Resveratrol Induces Apoptosis through ROS-Dependent Mitochondria Pathway in HT-29 Human Colorectal Carcinoma Cells". (2008) J Agric Food Chem 56(12): 48134818.

Pubmed | Crossref | Others

9. Wu, L., Zhang, L., Zhao, J., et al. "Cloning and Expression of a Transcription Factor Activator Protein-1 (AP-1) Member Identified from Manila Clam Venerupis philippinarum". (2015) Gene 557(1): 106-111. Pubmed | Crossref $\mid$ Others

10. Granado-Serrano, A.B., Martin, M.A., Bravo, L., et al. "Quercetin Modulates NF-Kappa B and AP-1/JNK Pathways to Induce Cell Death in Human Hepatoma Cells". (2010) Nutr Cancer 62(3): 390-401.

Pubmed | Crossref | Others

11. Singh, S., Sharma, B., Kanwar, S.S et al. "Lead Phytochemicals for Anticancer Drug Development”. (2016) Fron Plant Sci 7: 1667.

Pubmed | Crossref | Others

12. Duvoix, A., Blasius, R., Delhalle, S., et al. "Chemopreventive and Therapeutic Effects of Curcumin”. (2005) Cancer Lett 223(2): 181-190. Pubmed | Crossref | Others

13. Cilla, A., Attanzio, A., Barberá, R., et al. "Anti-Proliferative Effect of Main Dietary Phytosterols and B-Cryptoxanthin Alone or Combined in Human Colon Cancer Caco-2 Cells through Cytosolic $\mathrm{Ca}^{+2}-$ and Oxidative Stress-Induced Apoptosis". (2015) J Funct Foods 12: 282-293. Pubmed $\mid$ Crossref $\mid$ Others

14. Pocasap, P., Weerapreeyakul, N., Barusrux, S. "Cancer Preventive Effect of Thai Rat-Tailed Radish (Raphanus Sativus L. Var. Caudatus Alef)". (2013) J Funct Foods 5(3): 1372-1381.

Pubmed | Crossref $\mid$ Others

15. Syam, S., Bustamam, A., Abdullah, R., et al. “ $\beta$-Mangostin Induces P53-Dependent G2/M Cell Cycle Arrest and Apoptosis through ROS Mediated Mitochondrial Pathway and NFkB Suppression in MCF-7 Cells".(2014) J Funct Foods 6: 290-304.

Pubmed | Crossref| Others

16. Charles, C., Chemais, M., Stévigny, C., et al. "Measurement of the Influence of Flavonoids on DNA Repair Kinetics Using the Comet Assay". (2012) Food Chem 135(4): 2974-2981.

Pubmed | Crossref | Others 
Citation: Chen, S. Y., et al. Anti-Proliferative and Apoptotic Effects of Polygonum Cuspidatum and its Bioactive Compound, Emodin, in Colorectal Carcinoma HT-29 cells. (2018) Int J Food Nutr Sci 5(1): 16-24.

17. Lakshmi, T., Ezhilarasan, D., Nagaich, U., et al. “Acacia catechu Ethanolic Seed Extract Triggers Apoptosis of SCC-25 Cells". (2017) Pharmacogn Mag 13(Suppl 3): S405-S411.

Pubmed |Crossref $\mid$ Others

18. He, L., He, T., Farrar, S., et al. "Antioxidants Maintain Cellular Redox Homeostasis by Elimination of Reactive Oxygen Species". (2017) Cell Physiol and Biochem. 44(2): 532-553.

Pubmed | Crossref|Others

19. Lee, S. H., Park, M.H., Kang, S.M., et al. "Dieckol Isolated from Ecklonia cava Protects against High-Glucose Induced Damage to Rat Insulinoma Cells by Reducing Oxidative Stress and Apoptosis”. (2012) Biosci Biotechnol Biochem 76(8): 1445-1451.

Pubmed | Crossref| Others

20. Pacheco-Palencia, L.A., Mertens-Talcott, S., Talcott, S.T. "Chemical Composition, Antioxidant Properties, and Thermal Stability of a Phytochemical Enriched Oil from Acai (Euterpe Oleracea Mart.)". (2008) J Agri Food Chem 56(12): 4631-4636.

Pubmed | Crossref| Others

21. Droge, W. "Free Radicals in the Physiological Control of Cell Function". (2002). Physiolo Rev 82(1): 47-95.

Pubmed | Crossref| Others

22. Huang, C.Y., Hsieh, N.T., Pan, M.H., et al. "Resveratrol and Pterostilbene Regulate MED28 (magicin/EG1) Expression and Cell Growth in MCF7 Human Breast Cancer Cells". (2015) J Funct Foods 12: 158167.

Pubmed | Crossref $\mid$ Others

23. Lee, H.Z. "Effects and Mechanisms of Emodin on Cell Death in Human Lung Squamous Cell Carcinoma”. (2001) Br J Pharmacol 134(1): 11-20.

Pubmed |Crossref| Others

24. Yaoxian, W., Hui, Y., Yunyan, Z., et al. "Emodin Induces Apoptosis of Human Cervical Cancer Hela Cells via Intrinsic Mitochondrial and Extrinsic Death Receptor Pathway".(2013) Cancer Cell Int 13(1): 71. Pubmed |Crossref | Others

25. Lapidot, T., Walker, M.D., Kanner, J. "Can Apple Antioxidants Inhibit Tumor Cell Proliferation? Generation of $\mathrm{H}_{2} \mathrm{O}_{2}$ during Interaction of Phenolic Compounds with Cell Culture Media". (2002) J Agri Food Chem 50(11): 3156-3160.

Pubmed | Crossref | Others
26. Fukumoto, L.R., Mazza, G. “Assessing Antioxidant and Prooxidant Activities of Phenolic Compounds". J Agri Food Chem (2000) 48(8): 3597-3604.

Pubmed | Crossref $\mid$ Others

27. Braz, M.G., Favero Salvadori, D.M. "Influence of Endogenous and Synthetic Female Sex Hormones on Human Blood Cells in Vitro Studied with Comet Assay”. (2007) Toxicol in Vitro 21(5): 972-976.

Pubmed | Crossref | Others

28. Chang, J.S., Liu, H.W., Wang, K.C., et al. "Ethanol Extract of Polygonum cuspidatum Inhibits Hepatitis B Virus in a Stable HBV-Producing Cell Line". (2005) Antiviral Res 66(1): 29-34.

Pubmed | Crossref | Others

29. Chen, S.Y., Chyau, C.C., Chu, C.C., et al. "Hepatoprotection Using Sweet Orange Peel and Its Bioactive Compound, Hesperidin, for $\mathrm{CCl}_{4}$-Induced Liver Injury in Vivo". (2013) J Funct Foods 5(4): 15911600 .

Pubmed | Crossref $\mid$ Others

30. Hsieh, C.C., Hernández-Ledesma, B., de Lumen, B.O. "Cell Proliferation Inhibitory and Apoptosis-Inducing Properties of Anacardic Acid and Lunasin in Human Breast Cancer MDA-MB-231 Cells". (2011) Food Chem 125(2): 630-636.

Pubmed | Crossref | Others

31. Szeto, Y.T., Chu, W.K., Benzie, I.F. "Antioxidants in Fruits and Vegetables: A Study of Cellular Availability and Direct Effects on Human DNA”. (2006). Biosci Biotechnol Biochem 70(10): 2551-2555.

Pubmed | Crossref | Others

32. Yiu, C.Y., Chen, S.Y., Yang, T.H., et al. "Inhibition of Epstein-Barr Virus Lytic Cycle by an Ethyl Acetate Subfraction Separated from Polygonum cuspidatum Root and Its Major Component, Emodin”. (2014) Molecules 19(1): 1258-1272.

Pubmed | Crossref| Others

33. Zhao, M., Tang, S., Xin, J., et al. "Reactive Oxygen Species Induce Injury of the Intestinal Epithelium During Hyperoxia". (2017) Int J Mol Med 41(1): 322-330

Pubmed | Crossref | Others
Submit your manuscript to Ommega Publishers and we will help you at every step:

- We accept pre-submission inquiries

- Our selector tool helps you to find the most relevant journal

- We provide round the clock customer support

- Convenient online submission

- Thorough peer review

- Inclusion in all major indexing services

- Maximum visibility for your research

Submit your manuscript at

https://www.ommegaonline.org/submit-manuscript 